\title{
The pandemic, the future of children's health, and the development of pediatrics
}

The pandemic caused by severe acute respiratory syndrome coronavirus 2 (SARS-CoV-2) arrived in Argentina in the beginning of March 2020, after having a catastrophic effect in China and Europe, and after it began its most aggressive stage in the United States. Despite its scarce evidence, all the information published in medical journals indicated that a low incidence was apparently observed among children and, in any case, the impact of the disease was generally not severe. Similarly, newborn infants were not affected at all, or were seldom and minimally affected.

Argentina tried to be prepared in the best possible way: the National and Provincial Ministries of Health agreed on the imperativeness of implementing confinement, social distancing, and other measures that would allow time to strengthen the health care system and slow the growth curve of the number of cases. At the beginning, the compliance with these measures was almost universal and, as the months went by, it gradually decreased, in addition to the fact that some activities started being progressively allowed by the authorities. Nevertheless, the compliance with the closing of schools, kindergartens, and daycare centers was strict and universal.

There was also a greater awareness of hand washing and other aspects related to home hygiene among the population. It was really telling to see parents with their children walking on the streets while wearing homemade face masks and people communicating about extensive measures of home hygiene.

Undoubtedly, for parents of young children, especially for those who kept their jobs during the pandemic, this was and still is a huge challenge. The awareness among many parents of the risk of getting sick and passing it on to older adults, who are the most affected victims of this disease, was essential for maintaining isolation and selfcare in most cases.

The confinement, the lack of group games and social interaction, and the loss of routine had different negative effects on the population of children and adolescents, and its analysis will be essential in order to assess the situation globally. Other situations with significant implications for comprehensive health have also been identified.

The frequency of domestic accidents appears to have increased relatively, and there seems to be delayed consultation among many patients with ongoing diseases. ${ }^{1,2}$ In addition, an important percentage of delayed immunizations has been detected, mainly during the first year of life, as well as of delayed pediatric visits, which has a negative impact on growth follow-up, breastfeeding support, and the detection of developmental disorders. ${ }^{3,4}$

Conversely, it is worth noting the marked reduction observed in the frequency of respiratory infections. In fact, in the first 29 weeks of 2020, hospitalizations for bronchiolitis in the province of Buenos Aires decreased by $83 \%$ when compared to the same period in 2019. At a national level, in the first 24 weeks, they decreased by $80 \%$. When analyzing virus detection in lower respiratory tract infections, in the same period, respiratory syncytial virus (RSV) accounted for $2 \%$ of isolations, whereas in previous years it exceeded $60 \% .5,6$

This leads us to several considerations and questions. Many of us remember that, during the H1N1 epidemic, the incidence of other viral diseases also decreased. ${ }^{7}$ Furthermore, those of us who work in intensive care units noted that the frequency of nosocomial infections was much lower that year. Probably, an important factor contributing to this effect was that greater care was taken among members of the health care team for fear of contracting a high-risk disease; and in intensive care units, hand washing, among other things, was stricter during said pandemic. This situation is probably repeating itself during the coronavirus disease 2019 (COVID-19) pandemic.

Given the legacy of hygiene care and distancing brought about by the pandemic, will families maintain those precautions in the years to come? Will this learning be transferred to schools and daycare centers? Ironically, someone may suggest that, if that happens, pediatricians should be afraid of losing their jobs in the coming years. Or, on the contrary, will the respiratory syncytial virus reappear with more virulence after a year of low presence?

Pediatricians and members of the health care team have experienced changes in their daily practice, no matter where they work. The changing dynamics of the disease, uncertainty, and fears 
similar to those of the general population have heightened tension at work. All of this, together with, in many cases, excessive working hours due to colleagues getting ill and the transformation that took place in hospitals where it was necessary to repurpose pediatric areas for adults. ${ }^{8}$

The extended duration of this situation and the impossibility of precisely defining its length will probably contribute to increase the burnout syndrome typical of health care workers' practice and should therefore be also taken into account in the present and in the future. ${ }^{9}$

Given what has happened in other countries where the pandemic reached its peak, before than in Argentina, there is another concerning aspect: despite the efforts made to avoid this situation, the pandemic may exceed the health system's capacity and pediatricians may be required to care for adult patients. ${ }^{10}$ How will pediatric intensivists be affected both emotionally and professionally if this were to happen and beds in pediatric intensive care units were allocated to adults who would need to be cared for?

Going back to our patients, for those children who were "lucky" enough to have electronic entertainment, will we be able to detach them from these devices when returning to school, sports, and social activities? What will the school of the future be like? Will it be completely faceto-face or will we leverage some positive aspects of distance learning to avoid the harmful effect of overcrowded classrooms in some locations of the Metropolitan Area of Buenos Aires? What aspects will teachers be able to turn into their advantage regarding this situation?

For health care professionals, and especially for those who had to stay more isolated because they belonged to a risk population, this was and still is a learning process with many difficult aspects, but also positive ones. It was surprising to find out that high-quality ground rounds can be held remotely and attract more participants than face-to-face ones. Likewise, many conferences and symposiums were transformed into virtual activities with a large audience, costs were greatly reduced, and their educational power was still maintained (although the tourist aspect was removed, which can be considered positive or negative, depending on the point of view).

Teleconsultation has been widely accepted in some specialties, especially in technical ones, such as imaging; those that are based mainly on lab test results, such as nephrology or hematology; but also, others, such as psychology, psychiatry, etc. For pediatricians, who are certainly one of the groups of specialists who value the most sharing affection, shaking hands, placing a hand on a parent's shoulder, and giving a kiss to patients, these are gestures that will be difficult to see disappearing. The Argentine Society of Pediatrics has developed an intense activity reaching every corner of Argentina in order to discuss these issues.

Given the lack of certainties, children and their families need us today, maybe more than ever before. The challenge entails analyzing these changes and leveraging this experience in order to have, together with other specialists, a wide vision that would allow us to be better professionals in the future and respond adequately to these needs.

Néstor E. Vain, M.D. nestorvain@gmail.com Departments of Pediatrics and Neonatology, Sanatorios de la Trinidad Palermo, San Isidro y Ramos Mejía.

Gustavo R. Cardigni, M.D. gcardigni20@gmail.com

Department of Pediatrics, Sanatorio de la Trinidad Palermo.

Daniel R. Capra, M.D. dcapra@hotmail.com Department of Pediatrics, Sanatorio de la Trinidad Ramos Mejía Pediatric Intensive Care Unit, Hospital Nacional Prof. Alejandro Posadas

Buenos Aires, Argentina.

http:/ / dx.doi.org/10.5546/ aap.2020.eng.378

To cite: Vain NE, Cardigni GR, Capra DR. The pandemic, the future of children's health, and the development of pediatrics. Arch Argent Pediatr 2020;118(6):378-380.

\section{REFERENCES}

1. Bressan S, Gallo E, Tirelli F, Gregori D, et al. Lockdown: more domestic accidents than COVID-19 in children. Arch Dis Child. [Epub ahead of print, June 2 ${ }^{\text {nd }}, 2020$ ] 2020;archdischild-2020-319547.

2. French National Academy of Medicine. CoViD-19, containment and accidents in children's domestic life. Bull Acad Natl Med. [Epub ahead of print, May 15 ${ }^{\text {th }}, 2020$ ]. 2020;10.1016/j.banm.2020.05.016.

3. Tuñón I, Sánchez ME. Las infancias en tiempos de cuarentena. Observatorio de la Deuda Social Argentina UCA. Mayo 2020. [Accessed on: August $5^{\text {th }}, 2020$ ]. Available at: https: / / bit.ly/2YmWSSY.

4. Sociedad Argentina dePediatría. Encuentros virtuales 2020. El desafío de vacunar en pandemia. 2 de Julio de 2020. [Accessed on: August $\left.5^{\text {th }}, 2020\right]$. Available at: https: / / www. 
sap.org.ar/publicaciones/contenidos-extras/26/encuentrosvirtuales-covid-2020.html.

5. Argentina. Dirección de Epidemiología, prevención y promoción de la Salud. Ministerio de salud. Boletín epidemiológico semana 30 de 2020. [Accessed on: August $5^{\text {th }}$,2020]. Available at: http: / / www.ms.gba.gov.ar/sitios / media / files / 2020/07 / Bolet\%C3\%ADn-EPI-30.pdf.

6. Argentina. Dirección Nacional de Epidemiología e Información Estratégica. Ministerio de Salud. Boletín Integrado de Vigilancia, semana 26 de 2020. [Accessed on: August $\left.5^{\text {th }}, 2020\right]$. Available at: https: / / www.argentina.gob. ar/sites/default/files/biv_502_se_26_15-7.pdf.
7. Yang L, Chan KH, Suen LK, Chan KP, et al. Impact of the 2009 H1N1 Pandemic on Age-Specific Epidemic Curves of Other Respiratory Viruses: A Comparison of Pre-Pandemic, Pandemic and Post-Pandemic periods in a subtropical city. PLoS One. 2015; 10(4):e0125447.

8. Yager PH, Whalen KA, Cummings BM. Repurposing a Pediatric ICU for Adults. N Engl J Med. 2020; 382(22):e80.

9. Matsuo T, KobayashiD, Taki F, Sakamoto F, et al. Prevalence of Health Care Worker Burnout During the Coronavirus Disease 2019 (COVID-19) Pandemic in Japan. JAMA Netw Open. 2020; 3(8):e2017271.

10. Christian M, Kissoon N. Caring for Critically Ill Adults in PICUs Is not "Child's Play". Pediatr Crit Care Med. 2020; 21(7):679-81. 